\title{
Talking about antisemitism in MPA classrooms and beyond
}

\author{
Jamie Levine Daniel, IUPUI
}

Rachel Fyall, University of Washington

Jodi Benenson, University of Nebraska-Omaha

Forthcoming at Journal of Public Affairs Education

\section{Introduction}

...[A]n ethic of public administration asks us (administrators and citizens) to look squarely at our past experiences, acknowledge past tragedies, commit ourselves to inclusive solidarity with historical outsiders, and recognize possible goods that we might pursue as we move forward. (Alexander \& Stivers, 2010, p. 592)

On October 27, 2018, a gunman killed eleven people attending Shabbat services in the Tree of Life synagogue in Pittsburgh, PA. For many-both Jews and non-Jewsthis tragedy served as a wake-up call about the persistence of antisemitism ${ }^{1}$ in the United States today. For those who have been paying close attention, this incident added to increasing evidence that the cycle of antisemitism is taking another spin, with antisemitic sentiment intensifying worldwide (CST, 2019; Simon \& Schaler, 2007). For us - three Jewish professors in schools of public policy, public administration, and public affairs - the Tree of Life shooting prompted a deep dive into our own identities as well as our obligations and opportunities to ensure that rising generations of public servants are able to recognize and combat antisemitism whenever they encounter it.

\footnotetext{
${ }^{1}$ Antisemitism or anti-Semitism? Most American English dictionaries and spell-checkers hyphenate the term. However, the word "antisemitism" was invented for the purpose of adding a more scientific or modern frame to "hatred of Jews" (Lebovic 2018). In contrast, "Semitic" refers to a subgroup of northeast African and Middle Eastern languages that include, among others, Hebrew, Arabic, Amharic, and Tigrinya (Philogos, 2012). When hyphenated, anti-Semitism could be interpreted as referring to groups of people who speak these languages, rather than a specific hatred toward Jews. To preserve the original intent, "Antisemitism should be read as a unified term so that the meaning of the generic term for modern Jew-hatred is clear" (Lebovic, 2018). Therefore, we use the spelling antisemitism here unless directly quoting or citing a source that uses the hyphenated form.
}

This is the author's manuscript of the work published in final edited form as: 
Given our commitment to incorporating social equity, inclusion, and anti-racism into our courses, we are grateful for the theories, strategies, and examples provided by our colleagues that help frame and facilitate our classroom discussions on race and equity (e.g., Lopez-Littleton \& Blessett, 2015; Starke, Heckler, \& Mackey, 2018). We discovered we were shockingly unprepared when faced with the question, "If I want to talk about antisemitism in my classroom, what should I say?" We have now spent months thinking through this question, and we offer this article as a first take on the answer. We hope and intend for this article to serve as a resource for the public affairs ${ }^{2}$ community so our colleagues can feel prepared and empowered to address antisemitism in their classrooms. Our goal is to provide tools and language others can use to engage with this complicated topic of antisemitism.

We also seek to fulfill the pedagogical imperative of engaging with challenging topics inside public affairs classrooms (Love, Gaynor, \& Blessett, 2016), recognizing the importance of critical theory and critical pedagogy in the pursuit of social justice. Our motivation stems from our own emerging consciousness as individuals experiencing both privilege and oppression, depending on the context (Collins, 1990; Freire, 2000). We weave a more personal narrative based on our own experiences throughout the article, giving voice to some of the process and emotions we experience in this space and amplifying our message by mixing the personal with the generalizable (hooks, 2009).

Our whole professional lives, we had never considered bringing our Jewishness into the classroom. We never hid our identities, but being Jewish seemed irrelevant to our teaching goals and responsibilities. Of course, we nervously track news about

\footnotetext{
${ }^{2}$ We use the term public affairs as an inclusive reference that encompasses public administration, public management, and public policy.
} 
antisemitism (on our campuses, in our cities, worldwide), but this is not a topic we discussed with others, especially those at work.

Public affairs research and MPA curricula have rarely addressed contemporary antisemitism. Other than this article, the word "antisemitism" 3 appears only once in all $J P A E$ archives, where it is used within an example of the challenge of identifying diversity-related content in syllabi (Ryan, 2012). Moreover, antisemitism appears a total of 10 times in other top public administration and nonprofit journals, specifically Public Administration Review, Journal of Public Administration Research and Theory, Journal of Policy Analysis and Management, and Nonprofit and Voluntary Sector Quarterly. Of the limited mentions of antisemitism within the literature in our field, many focus on the Holocaust, discussing antisemitism exclusively in historical terms. For a striking example, within the index of Adams \& Balfour's Unmasking Administrative Evil (2015), the entry for antisemitism reads, “Antisemitism. See Holocaust and public affairs" (p. 217).

Looking beyond our field, discussions of antisemitism are also rare in higher education pedagogy and the scholarship of teaching and learning. Neither the International Journal for the Scholarship of Teaching \& Learning nor Teaching, Learning, \& Inquiry have a single mention of antisemitism. The Journal of the Scholarship of Teaching and Learning mentions antisemitism only once, when giving background information about a film (Greene et al., 2014). The field of multicultural education has also largely overlooked Jews and Jewish experiences (including antisemitism). As one scholar recounts, "No real discussion of Jews is present, in any capacity, in several prominent books in the field of multicultural education" (Rubin, 2017, p. 132). While a multitude of resources focus on teaching about the Holocaust,

\footnotetext{
${ }^{3}$ We also searched for "anti-Semitism" and related words.
} 
the primary evidence of antisemitism pedagogy at universities is within courses specifically focused on this topic (often taught in Jewish studies programs).

We met with a librarian; we assigned a research assistant to do literature searches; we asked our friends in other fields. The absence of research on how to teach about antisemitism feels like gaslighting. Is this not a pressing issue? Does anyone else notice its absence? Why hasn't someone else already done this work?

We argue that there are at least three reasons why introducing conversations about antisemitism within an MPA classroom supports and enhances our field's values and commitment to improving governance through education: 1) to create an awareness of the pitfalls of technical rationality; 2) to foster cultural competency among the next generation of leaders working in the diverse public and nonprofit sectors; and 3) to promote trust in institutions and ethical approaches for accessing power. These reasons reflect NASPAA's universal required competencies related to leading and managing in public governance, contributing to the policy process, critically thinking/solving problems/making decisions, applying a public service perspective, and interacting with both a diverse workforce and citizenry, as well as the specific cultural competency skills outlined by Lopez-Littleton and Blessett (2015).

Technical rationality is what Adams \& Balfour (2015) identify as a focus on efficiency, or the right way to do things. Taken to its extreme, technical rationality can result in "administrative evil" (Adams, 2011; Adams \& Balfour, 2015). Adams (2011) suggests that "the common characteristic of administrative evil is that people can engage in acts of evil without being aware that they are doing anything at all wrong" (p. 227). This dehumanization through technical expertise heralded the Holocaust - the most lethal act of antisemitism (and other hatred) in the past century. This administrative evil also manifested in other policy initiatives like Japanese internment, 
the Stanford Prison and Milgram Experiments, and the Tuskegee Syphilis Study. According to Starke, Heckler, and Mackey (2018), "it is necessary for public educators to problematize technical rationality, color-blindness, and the whiteness that reinforces these epistemologies" (p. 478).

Building cultural competencies is one way to counteract extreme technical rationality. These competencies are essential for preparing public and nonprofit leaders for $21^{\text {st }}$ century service (Carrizales, 2010; Haupt, Kapucu, \& Hu, 2017). Cultural competency reflects an understanding of how cultural characteristics can "create crosscultural misunderstandings" as well as how diversity can "contribute to the effectiveness of an organization" (Borrego \& Johnson, 2012, p. 7). Public and nonprofit managers have to manage diverse, multicultural organizations that service diverse, multicultural populations. Cultural competency often focuses on "the Black-White binary," overlooking other aspects of population diversity such as gender diversity, ethnic background, sexual orientation, and religion (Lopez-Littleton \& Blessett, 2015, p. 558). Including these additional complexities in cultural competency curricula helps counteract racism alongside other forms of bias, such as antisemitism.

In addition to fostering cultural competency, teaching about antisemitism in public administration classrooms also promotes trust in institutions and ethical approaches for accessing power. As we discuss further below, a classic theme in antisemitism is that coordinated, covert Jewish power is omnipresent, working against the shared public values of transparency, fairness, and equal opportunity ("AntiSemitism”, 2010). Framing Jews as behind-the-scenes puppeteers with outsized power undercuts public trust in institutions (including government) and their defined channels of authority. In this way, a belief in (or inability to recognize) antisemitism undermines the ability of Jewish students to access power without being subject to extra scrutiny, 
the ability of non-Jewish students to elevate powerful institutions as transparent and trustworthy, and influences the ability of both to elevate Jewish employers and leaders.

What if we haven't convinced you? Raising this issue makes us vulnerable, but there's a greater risk that staying silent allows for a thousand missed opportunities to combat antisemitism across our collective spheres of influence.

What should we say when we talk about antisemitism? What should we teach our MPA students? U.S. history includes policies that discriminate against Jews (e.g., restrictions on property ownership, quotas on immigration and public university enrollment), but leading with these policies misses the complexity of antisemitism. Jews were (and are) discriminated against, but they are not disproportionately represented among the poor. ${ }^{4}$ And herein lies the unique liability of the Jews-our seemingly magical capacity to gain more power and influence than we rightfully deserve (Ward, 2017).

Given the history of antisemitism and its current prevalence, this article serves as a primer for background and ideas that facilitate conversations on antisemitism within MPA classrooms. We start with a brief overview of Jewish identity and demographics. We follow by defining antisemitism and contextualizing antisemitism on college campuses. We then offer classroom approaches as well as institutional and personal actions that can be used to teach about and address antisemitism.

\section{Who are Jews?}

Jewish literacy — an understanding of Judaism, Jewish history, and the Jewish community—is an important tool for combating antisemitism (Price \& Silverman,

\footnotetext{
${ }^{4}$ Given the inter-correlations between educational attainment, race, and religion, it is challenging to identify a unique relationship between religion and wealth. According to the Pew Research 2014 Religious Landscape Study, Jews, Hindus, and Episcopalians live in households with incomes of at least $\$ 100,000$ at the greatest rates $(44 \%, 36 \%$, and $35 \%$, respectively), and these groups also have high levels of educational attainment (Masci, 2016).
} 
2019). Without adequate Jewish literacy, conversations about Jews and antisemitism risk reinforcing antisemitic stereotypes and further marginalizing Jewish students, faculty, and staff. To promote basic Jewish literacy, we present identity and demographic background in this section.

Jews identify as such through religion, culture, ancestry, ethnicity, and/or race. The worldwide Jewish population numbers approximately 14 million people, representing about $0.2 \%$ of the world's population (Pew Research Center, 2012). Approximately $80 \%$ of the world's Jews live in the United States (U.S.) and Israel. Israel is the only nation in the world with a majority of Jews ( $\sim 95 \%$ of the population). The U.S. Jewish population is 7.2 million people, 4.2 million of whom are adults ( $\sim 1.8 \%$ of the total U.S. adult population). For historical context, surveys from the 1950s-1960s regularly found 3-4\% of American adults identifying their religion as Jewish (Lipka, 2013).

The current Jewish population skews older, female, educated, and Democratic (“American Jewish Population Project Current Estimates”, n.d.). Approximately 26\% are over 65 years old, compared to $19 \%$ of the general U.S. population, and female ( $53 \%$ women). Over $58 \%$ are college graduates, including $29 \%$ with postgraduate degrees (general population: $29 \%$ college graduates, including $10 \%$ with postgraduate degrees). In addition, all but $4 \%$ live in urban or suburban areas, with $43 \%$ of the Jewish population concentrated in the Northeast (Pew Research Center, 2013).

According to the Steinhardt Social Research Institute's American Jewish Population Project 2015, more than 1 in 10 U.S. Jewish adults identify as non-White. Be'chol Lashon, the research arm of the Institute for Jewish \& Community Research, estimates that approximately 600,000 Jews in America have some Sephardic (Spanish or Iberian) heritage in addition to the $10 \%$ who identify as Black, Asian, Latino, or 
mixed-race. Taken together, they estimate that at least $20 \%$ of the Jewish population includes Jews by ancestry, adoption, and/or marriage who are African, African American, Latino (Hispanic), Asian, Native American, Sephardic, Mizrahi (descended from Middle Eastern Jewish communities) and/or mixed race ("Counting Jews of Color in the United States," n.d.).

We have each struggled with reconciling being White and being Jewish, whether it is in checking off a demographic box, or discussing what is commonly thought to be White history in the U.S. Are we White? In our lived experiences in the U.S. context, we generally benefit from White privilege. Yet when we talk about race in the U.S. context, we often feel that identifying as "White" seems to undermine our Jewishness. But when we travel - to Europe, to Egypt, to parts of the U.S. where many people have never met a Jew-we feel like we're "passing." We wonder if we're "passing." We don't want to put ourselves in danger by revealing our Jewishness.

\section{Defining antisemitism}

"We are fighting an enemy that is different from us. Not open, but hiding; not straightforward but crafty; not honest but base; not national but international; does not believe in working but speculates with money; does not have its own homeland but feels it owns the whole world." -- Viktor Orban, Prime Minister of Hungary, on George Soros (As quoted by Shaun Walker in The Guardian on March 15, 2018)

Recognizing and addressing antisemitism requires familiarity with the basic beliefs and tropes that constitute antisemitism. While a large body of academic and popular literature delves into antisemitism, this section offers a colloquial overview of antisemitism, grounded primarily in recent gray literature and popular writings. Appendix A offers additional recommended readings on contemporary antisemitism.

At its core, antisemitism is hatred of or prejudice toward Jews (“Anti-Semitism", 2010; Beller, 2015; USHMM, n.d.). As Marcus (2015, p.14) describes in greater detail, 
antisemitism is "a set of negative attitudes, ideologies, and practices directed at Jews as Jews, individually or collectively, based upon and sustained by repetitive and potentially self-fulfilling latent structure of hostile erroneous beliefs and assumptions that flow from the application of double standards toward Jews as a collectivity, manifested culturally in myth, ideology, folklore, and imagery, and urging various forms of restriction, exclusion, and suppression."

Antisemitism is similar to other forms of hate and prejudice, but key differences lie in the perceptions of power and ability. As Vox's Coaston (2018) writes,

[W] hile anti-black racism or white supremacy revolve around on the (wrong) idea that black people or nonwhites are inferior, anti-Semitism, as practiced by many of its adherents today from a number of political and social backgrounds, is based on the idea that Jewish people have too much power, or even that Jewish people are secretly in charge - of the government, of culture, of the world in its entirety. (Coaston, 2018)

Antisemitism, sometimes referred to as "the longest hatred" (USHMM, n.d.; Wistrich, 1992), dates back thousands of years. While the specific language and accusations associated with antisemitism evolve over time, common themes or "tropes" unite this particular form of hate. Historically, antisemitic messages centered around two types of images and tropes: dehumanization and stereotypes. Dehumanization images portray Jews as demons, blood drinkers, and/or vermin. Stereotypes include Jews as rich money grubbers who control the banks, media, and any given country's government. According to Kirschen (2010), taken together, these categories portray Jews as "rich, ugly, demonic, powerful and enemies of the social order" (p. 436).

After a few decades (i.e., post-Holocaust) where open expressions of antisemitism were considered problematic, Kirschen's third category emerged: moral inversion. In this expression, "Jews are portrayed as the perpetrators rather than the 
victims. In this case, Jews are essentially depicted as Nazis" (p. 436). The taboos that formerly held such animus in check weakened and, in some circles, fell altogether. Charges about Jewish "control" of the media, international finance, and political power, which not long ago were considered unacceptable in mainstream society, are now openly expressed (Rosenfeld, 2015, p. 3). The Orban quote at the beginning of this section is one example of this open expression, using antisemitic imagery to (mis)characterize George Soros, a Hungarian-American Jewish Holocaust survivor and prominent philanthropist.

One antisemitic stereotype manifests in the belief of a "hidden conspiracy of Jews that is ceaselessly working to overturn all natural laws and settled social arrangements in furtherance of their own malignant ends" (Newhouse, 2018). In fact, as Kirschen (2010) explains, "By proclaiming the existence of a powerful, secretive, demonic enemy, [movements] build a shared hatred as a unifying force for recruitment of adherents" (p. 6). Antisemites believe that Jews cannot be trusted or loyal to their countries.

We feel powerless in our attempts to counter the myth of the secretive, untrustworthy Jew. Because of this myth, Jewish voices are not seen as credible when we call out antisemitism. We need help from our allies.

Demonization and stereotyping are often visible on the political right. In September 2018, a campaign mailer sent on behalf of the Republican candidate for Connecticut State Senate portrayed his Jewish opponent "clutching a fistful of money" (Vigdor \& Beals, 2018). President Donald Trump himself accused George Soros of funding protests against then-Supreme Court nominee (now current Associate Justice) Brett Kavanaugh (Trump, 2018). In fact, a 2018 article in Fast Company provides a timeline of many of the conspiracy theories tied to George Soros. According to sources 
such as Slovakian president Jan Slota, Malaysian prime minister Mahathir bin Mohamad, Russian president Vladimir Putin, and media pundits such as Bill O'Reilly, Glenn Beck and Rush Limbaugh, and Tomi Lahren, Soros is responsible for or has funded everything from coups d'etat across the world to currency crises to Colin Kaepernick (Baram, 2018). Common language here includes references to "globalists" and myths about Jewish conspiracies, and is often used by white nationalists and neoNazis.

On the political left, antisemitism often presents itself through rhetoric as a form of moral inversion. Writers in both Jewish and mainstream outlets (Pildis, 2018a, 2019; Pagano, 2018; Schmidt, 2019; Stockman, 2018) have written extensively about conflicts surrounding antisemitism in the Women's March, including a failure to include Jewish women in its original Unity Principles and an ongoing association with open antisemite Louis Farrakhan. People carrying Jewish pride flags have been kicked out of pride marches in Chicago and New York City (Greenblatt, 2017). Great Britain's Labour Party, long representing the political left, recently saw the resignation of nine sitting Members of Parliament over accusations of antisemitism as institutionalized within the party (Sabbagh, 2019). As Pildis (2018b) argues, "The far right has blood on its hands, but the left is not innocent. The social justice movement has failed us repeatedly over the past two years".

\section{A note on Zionism, anti-Zionism, and antisemitism}

Antisemitism often co-occurs with conversations about Israel and Zionism. "Zionist is an incredibly loaded word. For some it means the belief that Israel has a right to exist. For others it signifies supporting the oppression of the Palestinian people" (Schuffman, 2019). Criticisms about specific Israeli policies, actions, or political leaders are not antisemitic. Similarly, defenses of Palestinians are not inherently antisemitic 
(Loucaides, 2019). These critiques have the potential to become antisemitic when they generalize to all Jews or hold all Jews responsible for the actions of the State of Israel, what Kirschen (2010) would consider an example of the moral inversion trope.

Criticism of Israel also becomes antisemitic when the existence of the State of Israel is framed as inherently racist, denying Jewish people the right to selfdetermination. Deborah E. Lipstadt, a scholar of Jewish history, notes that applying double-standards to Israel is often key to identifying critiques that veer into antisemitism:

"Many anti-Israel advocates contend that the fact that Israel is a country with an established state religion renders it archaic, and this justifies its dissolution. They are strangely silent on the validity of the nondemocratic Islamic theocracies in the same neighborhood. And the fact that Great Britain, Denmark, Greece, and Monaco have official state religions doesn't seem to bother them, either." (Lipstadt as quoted in Chotiner, 2019)

Similarly, equating Israel to European colonization denies a connection between Jews and the Middle East that is foundational to Jewish history and identity (Jacobs, 2018).

\section{Antisemitism in the U.S., on campus, and in the classroom}

While the fatal shooting in Pittsburgh spurred/reignited conversations around antisemitism in the United States, displays of antisemitism have plagued the United States for decades, including on college campuses. Each year, the Anti-Defamation League (ADL) conducts an annual Audit of Anti-Semitic Incidents, and the most recent audit found that there were 1,986 antisemitic incidents reported across the United States in 2017. These reports include physical attacks, vandalism, and attacks on Jewish institutions. This number was a 57\% increase from 2016, with incidents taking place in every state across the country (Anti-Defamation League, 2018). Hate crime data from 
the Federal Bureau of Investigation (2018) also confirm these increases.

The ADL also found that in 2017 there were 1,015 incidents of harassment, including 163 bomb threats against Jewish institutions, up 41 percent from 2016; 952 incidents of vandalism, up 86 percent from 2016; 19 physical assaults, down 47 percent from 2016. The ADL notes that the rise was in part due to a significant increase in incidents in schools and within higher education institutions, which nearly doubled. College and university campuses saw a total of 204 incidents in 2017, compared to 108 in 2016. American schools and colleges/universities saw an $89 \%$ increase in antiSemitic acts in 2017 (Anti-Defamation League, 2018).

A variety of antisemitic incidents have been reported on college campuses. Some of these activities are correlated with the increasing level of activism on college campuses as part of the anti-Israel Boycott, Divestment and Sanctions (BDS) movement, but the most common reports are those of swastikas drawn on buildings, bullying, and assault (Anti-Defamation League, 2018; AMCHA Initiative, 2017; BauerWolf, 2018). A study by Kosmin and Keysar (2015) finds that over half of Jewish students in the sample experienced or witnessed antisemitism. Saxe, Sasson, Wright, and Hecht (2015) found that about one-third of Jewish students have been harassed (verbally or physically) because they were Jewish. Wright, Shain, Hecht, and Saxe (2017), however, find that hearing hostile remarks toward Israel was more prevalent than exposure to antisemitic statements.

Students experiencing antisemitism on campus largely see other students as the source, rather than faculty or institutions (Koren, Saxe, \& Fleisch, 2016). Yet, the ways in which a university responds to major antisemitic incidents (on- or off-campus) are important for all students, faculty, and staff. The script goes more or less like this: An incident occurs. The public is shocked and saddened. The university president (and/or 
school dean) sends out an email blast condemning such terrible acts and expressing support for the victims and their community, often concluding with a statement of solidarity and a promise to work toward preventing such ills in the future. Most often, no further action is taken.

The act of a response letter from leadership as a kind of organizational ritual (Meyer \& Rowan, 1977), signaling the aspired values of the institution and its leadership. The ritual of a public response offers important symbolic support. This, of course, assumes that a university administration has a policy in place to deal with such conflict.

Thus, in the hours and days following an antisemitic act, we silently wonder: Does this "count" as a focusing event? Will it be worthy of a public response from our institutional leaders? In the wake of the August 2017 "Unite the Right" rally in Charlottesville, VA-a rally during which self-proclaimed neo-Nazis chanted "Jews will not replace us!"-we held our breaths for the response. Our university leaders did respond, condemning hatred and racism, but the word "antisemitism" and specific references to Jews were noticeably (painfully) absent.

In addition to blatantly antisemitic incidents of the kinds described above, departments and universities often send unintentional signals of closed or unwelcome spaces. For faculty members, scheduling the first week of classes, required exam dates, or faculty meetings on Jewish holidays (and those of other, non-Christian religions) makes being a full citizen of the department impossible. Sponsoring community-wide events on these days prevents these events from being truly open to the full community. These scheduling patterns also send signals to Jewish students that campus may not be welcoming.

We are so tired of bringing up the Jewish calendar every year. We feel like 
people hear us and think, "There she goes with the Jewish stuff again, " pigeonholing us as one-issue women and potentially devaluing other contributions we are making to the department.

\section{The MPA classroom: What can we do?}

MPA classrooms likely include Jewish students, students with Jewish family members, and/or antisemites. The 2015 update of the Anti-Defamation League's global survey of antisemitism estimates that $10 \%$ of American adults harbor antisemitic attitudes (Anti-Defamation League, 2015). Depending on university location and student recruitment patterns, MPA students may not have any basic knowledge about Judaism or antisemitism.

Given the prevalence and endurance of antisemitism in the U.S. and worldwide, along with the aims and ambitions of public affairs education, discussions about antisemitism deserve a place in MPA classrooms. Discussions of antisemitism must be rooted in social justice approaches to education, which are standpoints and scholarly traditions that actively address the dynamics of oppression, privilege, and isms, recognizing that society is the product of historically-rooted, institutionally sanctioned stratification along socially constructed groups (Cochran-Smith, 2004). To educate through a social justice lens in MPA classrooms, we must guide students in critical selfreflection of antisemitism and its implications, analysis of the mechanisms of oppression, and the ability to challenge these hierarchies, which reflect the aims of critiquing technical rationality, building cultural competencies, and promoting trust in and access to public and nonprofit institutions. Drawing from our own classroom experiences, review of our course syllabi, and consultations with colleagues, this section offers suggestions for how to incorporate conversations about antisemitism into public affairs course content. We start with an example of how we broached the topic, then 
offer course-specific suggestions, and conclude with suggestions for general talking points and instructor preparation.

Beginning the conversation. Following the Tree of Life Synagogue shooting, we posted some optional readings on antisemitism on our class webpage (Appendix A lists some possible readings), and we gave the students the option to dedicate some time in class to discuss this issue. Many voiced a preference for class time, even if they had not prioritized the readings, offering comments like, "I have not learned a lot about [antisemitism] or discussed it outside of its context in the Holocaust" and "I have never had the opportunity to discuss antisemitism in a classroom setting." Our Jewish students also appreciated the opportunity to make space for this discussion: "As someone who is Jewish but has only infrequently felt direct impacts of antisemitism, I often feel unclear of how to relate antisemitism to broader discussions of racism in the American context."

We began one mini-lecture on antisemitism with an overview of demographics: How many Jews are there worldwide? In the U.S.? In Israel? How does one even count who is Jewish? (The Pew Research Center's "Jewish Population Calculator" is an insightful tool.) What does it mean to be a Jew anyway—is it religion? Culture? Ancestry? Race? Displaying the demographics offers an easy foray into the topic, as many students recognize the mismatch between the numerical minority status of Jews worldwide, and the outsized visibility of and rhetoric around Jews (and Israel). After establishing this basic Jewish literacy, we then articulated the basic tropes of antisemitism.

Recommendations for specific courses. While a one-off conversation about antisemitism could be appropriate for any public affairs course, we also need to consider the social justice competencies around antisemitism that could be developed in specific courses through activities, exercises, discussions, and assignments. These 
suggestions reflect NASPAA's universal required competencies, and include: describing the concept of diversity as well as the diversity of individuals and populations in a community or network, facilitating communication among individuals/groups/organizations, leading and managing in public governance, thinking critically/solving problems/making decisions, and articulating a public service perspective. Table 1 presents a sample list of courses documenting how addressing antisemitism may be embedded within public affairs education, including LopezLittleton and Blessett's (2015) more specific cultural competencies, and we discuss these examples below.

[Table 1 about here]

In public management courses, one way to incorporate discussions of antisemitism is to include Schneider and Ingram's 1993 article on social construction of target populations. Revisiting their Figure 1 (Schneider \& Ingram, 1993, p. 336), antisemitism can be discussed as a framing of Jews as "Contenders," which contrasts with the biased frames often used to characterize People of Color as "Dependents" or "Deviants." This framing connects antisemitism both to course material on the policy process and discussions on racism in public policy and administration. Doing so helps uncover the stereotypes, prejudices, and policy design targeting Jewish people and People of Color, highlighting the important role social constructions play in influencing the policy agenda, the selection of policy tools, and the legitimization of policy choices. Furthermore, classes that incorporate social construction and critical theory can look at who is shaping the conversations around antisemitism. As Schraub (2019) notes, "The nation is having a conversation about Jews virtually impervious to the input of 
Jews themselves." Without input from the community experiencing the phenomenon, attempts to address it appear to "use anti-Semitism for political purposes while further marginalizing the Jewish community" (Schraub 2019).

Nonprofit classes often include content related to fundraising, altruism, and community mobilizations - all of which offer a useful lens for relating to the range of responses in the wake of a tragedy. For example, in the aftermath of the Pittsburgh shooting, we linked McChesney’s (1995) work about charity and Islam (which had coincidentally been assigned for that day) with Melendez's (2018) Daily Beast article about Muslim fundraising for victims of the shooting. The site of the massacre within a house of worship also connects with religious institutions as an important foundation of civil society and the nonprofit sector, both in the U.S. and internationally.

Courses focused on policy analysis, the policy process, and the U.S. government could focus on lawmakers' attempts to intervene in response to antisemitism. In 2017, the U.S. House Committee on the Judiciary held a hearing on antisemitism on college campuses, and recommended that the U.S. Department of Education (DOE) adopt a "clearer definition of what constitutes harassment toward Jewish students, to ensure that future investigations into anti-Semitic acts are easier to conduct" (Rockenbach, Selznick, \& Mayhew, 2018). In addition, the Anti-Semitism Awareness Act, introduced in 2016, would have instructed the DOE to rely on the State Department's definition of antisemitism. The bill passed in the Senate but not the House in 2016, creating debate with some opponents arguing that the State Department's definition would "chill free speech on at universities" (Bauer-Wolf, 2017). ${ }^{5}$ These situations could be turned into case studies or other pedagogical materials to engage conversation and debate.

\footnotetext{
${ }^{5}$ According to Bauer-Wolf (2017), the State Department's definition includes "demonizing Israel as an example of antisemitism, and opponents felt this would suppress opposition to the actions of the Israeli state among both students and professors." For more information and a take from The Alliance for Academic Freedom, see Nelson et al. (2018).
} 
Students in policy evaluation courses can be introduced to antisemitism when discussing culturally responsive evaluation. Culturally responsive evaluation is a framework for centering evaluation in culture (Frierson, Hood, Hughes, \& Thomas, 2010; Hood, Hopson, \& Kirkhart, 2015), and recognizes that culturally defined values and beliefs lie at the heart of any evaluative effort. Taking this holistic evaluation approach to focus on groups that have been historically marginalized can invite conversations about antisemitism and other concepts when discussing ways to bring balance and equity into the evaluation process.

In human resource management courses, students could be exposed to successful human resource models that incorporate understanding of what antisemitism may look like in a work environment. This will allow students to consider, for instance, what policies might need to be put in place when a Jewish employee requests a day off to observe a Jewish holiday, or what should be done when antisemitic behaviors, actions, or beliefs are present in an organization. Employees in the public and nonprofit sectors must be aware that antisemitic individuals may be present in the workplace, and should therefore be vigilant in treating any antisemitic message or act the same as any other unlawful harassment in the workplace. Exposing students to these examples and providing suggestions for action will provide students with the competencies to create and manage processes to improve organizational performance.

Research methods or quantitative-focused classes might consider discussing antisemitism in the context of data, expanding on the challenges mentioned earlier related to demographics. The tracking of hate crimes offers another link between policyrelevant data and antisemitism. In the absence of a clear connection with course material, personal reflection is always an option. Instructors who do not identify as Jewish can discuss their own experiences of learning about or witnessing antisemitism. 
Inviting a Jewish colleague or public or nonprofit practitioner as a guest speaker on antisemitism is always an option.

General course content. This section so far has focused on intentional incorporation of antisemitism into MPA curricula. However, anyone who refers to or expects students to discuss current events should have some talking points prepared for when the subject arises. Processing antisemitic events through a frame focused on critiquing technical rationality, building cultural competence, and building ethical, accessible public and nonprofit institutions highlights the impact of antisemitism on the very work in which our students are engaged.

In addition, America's relationship with Israel is often in the news. Being prepared to differentiate between policy critiques that are connected to specific political actions and stereotypical antisemitic tropes models the cultural competence we hope to engender in our students. In facilitating or introducing conversations about Israel, it is helpful to start with a clear statement acknowledging both the value of critique and the risk of antisemitism. ${ }^{6}$ In the case that student comments venture into potentially antisemitic territory, hypothetically swapping "Israel" with another nation or "Israelis" with a different marginalized community can be illuminating. Students may resist the framing of "Israelis" as marginalized, particularly in politically liberal settings, but this provides an opportunity for unpacking the "matrix of domination" wherein Israeli Jews can be simultaneously privileged and oppressed (Collins, 1990).

A challenge in higher education is to prepare the next generation of MPA instructors to teach in a way that demonstrates a commitment to diversity and inclusion

\footnotetext{
${ }^{6}$ For example, "During our discussion, I ask that you please keep in mind the unique status of Israel as the only nation with a Jewish majority population. While specific criticisms of the Israeli government and its policies are appropriate and valid, broad generalizations about Israel and Israelis risk perpetuating antisemitism."
} 
and to accept ownership of their own implicit biases around antisemitism.

Conversations on implicit bias should be incorporated into teaching workshops for students, and these conversations should be supplemented with resources such as Harvard's Implicit Association Test (IAT) and other relevant readings/exercises.

Findings from the Interfaith Diversity Experiences and Attitudes Longitudinal Study (2018) suggests that interventions within higher education institutions can contribute to shifts in attitudes about Jews. Mayhew et al. (2018) find that appreciative attitudes toward Jews varied by students' perceptions of structural, psychological, and behavioral climate dimensions related to worldview. The authors also find that educational experiences that invite informal experiences interacting with diverse peers, self-reflection on one's assumptions, and interfaith engagement with students of other beliefs contribute to students' appreciation of Jews. Self-reflective activities also provide space for revealing identities (like being Jewish or sexual identity), where students otherwise might not consider these identities relevant to the discussion. The authors also recommend providing campuses with resources and support, which may serve as a campus-wide signal that Jews and Judaism are valued and important.

Like all of our teaching, it is difficult to know what sticks for students, though sometimes we have the opportunity to hear it directly from them, as one student relayed in an end-of-semester closing comment:

As a fellow Jewish woman, I would like to say thank you for the discussion you led on antisemitism. Although it is a hard topic for me, I feel that there is so much value in acknowledging this sort of hatred that exists in our world today. I appreciate you speaking from your own experience. Specifically, hearing your thoughts on how antisemitism still exists in left-wing politics resonated with me. 
Unfortunately, I have recently heard so much discussion on the Israel-Palestine dispute that has anti-Semitic undertones. I never knew what to make of the way these discussions made me feel being that I don't necessarily agree with Israel's political decisions. However, hearing you speak on the subject really helped me to have a better understanding of why these discussions often rub me the wrong way. I just wanted to say thank you for that. I know that is not an easy thing to talk about, but it means a lot to me and I'm sure it meant a lot to other students in the class as well.

\section{Beyond the classroom and towards a more inclusive future}

Outside of the classroom setting, departments and institutions can build in practices that signal cultural competence and engender trust, such as creating a departmental policy for religious accommodations. For example, departments with shared calendars or where coordinators email professors with important dates (university closures, exam schedules, etc.), including Jewish (and other) holidays students may observe can create awareness for faculty that leads to more inclusive course-planning. This type of course planning can help remove administrative burdens for Jewish students and create welcoming classroom environments. See Appendix B for an example of such language.

Individual actions by colleagues and students - particularly after antisemitic incidents - are also important, and help Jewish members of the department feel acknowledged and valued. Simple emails or check-ins with Jewish colleagues and students communicate welcome allyship.

"You and your family have been in my thoughts. If I can do anything to make you feel even a little safer, please let me know."

"I'm not sure what to say, but I wanted to write."

"I've been thinking of you during these last few days of anti-Semitic horror." 
"How are you holding up? It's been a tough week."

"I just wanted to check in to see if you're okay."

However, as a field, we have more work to do when it comes to preparing students to identify and address antisemitism.

This framing (critiquing technical rationality, cultural competency, trust) made us feel comfortable discussing antisemitism with our students. For the first time, it was not only about us or our own personal experiences and biases, but also about systemic change towards a more inclusive (and less hateful) future.

We must continue to conduct research on the implications of including important conversations about antisemitism in public affairs. We must also create resources such as case studies, databases, and journal articles so that educators will be equipped to teach antisemitism in the classroom. Doing so will allow us to understand what impact, if any, these conversations have on students, faculty, and communities. We can also conduct research both within our classrooms and across our field on the attitudes and/or knowledge bases of students, faculty, and public administrators on topics related to antisemitism to better understand the support and resources that might be needed in classrooms. A better understanding of institutional and departmental needs related to equity and inclusion will strengthen our classroom toolkits to engage on complex topics like antisemitism. In addition, this topic would benefit from additional critical theory analysis to highlight the root causes and manifestations of discriminations and injustices and why they matter to public administration, as well as antisemitism's broader connections to other targeted forms of discrimination. We set out to provide a resource for engaging with the complicated topic of antisemitism, and hope this article prepares and empowers our colleagues to do so.

Thank you. We are grateful to have you as colleagues and allies. 


\section{References}

Adams, G. B. (2011). The problem of administrative evil in a culture of technical rationality. Public Integrity, 13(3), 275-285.

Adams, G. B., \& Balfour, D. L. (2015). Unmasking Administrative Evil (4 ${ }^{\text {th }}$ Edition). Armonk, NY: M. E. Sharpe.

Alexander, J., \& Stivers, C. (2010). An Ethic of Race for Public Administration. Administrative Theory \& Praxis, 32(4), 578-597.

AMCHA Initiative (2017). Antisemitism: At the Epicenter of Campus Intolerance. Retrieved from https://www.amchainitiative.org/wpcontent/uploads/2017/04/Antisemitism At-the-Epicenter-of-CampusIntolerance Report-2016.pdf.

"American Jewish Population Project Current Estimates." (n.d.). Steinhardt Social Research Institute. Retrieved from http://ajpp.brandeis.edu/publications.php\#section3. (Accessed January 29, 2019).

Anti-Semitism. (2010). In J. M. Levine \& M. A. Hogg (Eds.), Encyclopedia of Group Processes \& Intergroup Relations (Vol. 1, pp. 22-25). Thousand Oaks, CA: SAGE Reference. Retrieved from http://ink.galegroup.com/apps/doc/CX3202000019/GVRL?u=wash main\&sid= GVRL\&xid=ee7609e2. (Accessed 3/18/2019).

Anti-Semitism Awareness Act of 2016. https://www.congress.gov/bill/114thcongress/senate-bill/10/text.

Anti-Defamation League. (2015). "The ADL Global 100: An Index of Anti-Semitism, 2015 update." Retrieved from global100.adl.org/\#country/usa/2015. (Accessed 3/18/2019).

Anti-Defamation League. (2018). 2017 Audit of Anti-Semitic incidents. Retrieved from https://www.adl.org/resources/reports/2017-audit-of-anti-semitic-incidents

Baram, M. (2018, October 5). Buckle up! Here's a timeline of George Soros conspiracy theories. Fast Company. Retrieved from

https://www.fastcompany.com/90247335/a-timeline-of-george-sorosconspiracy-theories.

Bauer-Wolf, J. (2017, November 8). House Committee Takes Anti-Semitism College Campuses. Inside Higher Ed. Retrieved from https://www.insidehighered.com/news/2017/11/08/house-committee-takes-antisemitism-college-campuses.

Bauer-Wolf, J. (2018, December 5). Anti-Semitic Incidents Surge College Campuses After Pittsburgh Synagogue Shooting. Inside Higher Ed. Retrieved from https://www.insidehighered.com/news/2018/12/05/anti-semitic-incidents-surgecollege-campuses-after-pittsburgh-synagogue-shooting.

Beller, S. (2015). Antisemitism: A very short introduction, 2nd edition. Oxford: Oxford University Press.

Borrego, E., \& Johnson, R. G. (2012). Cultural competence for public managers: Managing diversity in today's world. Boca Raton, FL: CRC Press.

Carrizales, T. (2010). Exploring cultural competency within the public affairs curriculum. Journal of Public Affairs Education, 16(4), 593-606.

Chotiner, I. (2019, January 24). Looking at anti-Semitism on the left and the right: An interview with Deborah E. Lipstadt. The New Yorker. Retrieved from https:/www.newyorker.com/news/the-new-yorker-interview/looking-at-anti- 
semitism-on-the-left-and-the-right-an-interview-with-deborah-e-lipstadt (Accessed April 15, 2019).

Coaston, J. (2018, October 31). How the rise of conspiracy theory politics emboldens anti-Semitism. Vox. Retrieved from https://www.vox.com/identities/2018/10/31/18034256/anti-semitism-pittsburghsynagogue-shooting-prejudice-right.

Cochran-Smith, M. (2004). Walking the road: Race, diversity, and social justice in teacher education. New York, NY: Teachers College Press.

Collins, P. H. (1990). Black feminist thought in the matrix of domination. In C. Lemert (Ed.) Social Theory, 2nd Edition (pp. 553-564). Boulder, CO: Westview Press.

Community Security Trust [CST]. (2019). Antisemitic incidents: Report 2018. Retrieved from https://cst.org.uk/publications/cst-publications (March 1, 2019).

Counting Jews of Color in the United States. (n.d.). Retrieved February 8, 2019 from http://www.bechollashon.org/population/north america/na color.php.

Federal Bureau of Investigation (2018). FBI - Hate Crime Statistics. Retrieved from: https://ucr.fbi.gov/hate-crime

Freire, P. (2000). Pedagogy of the oppressed. New York: Continuum.

Frierson, H. T., Hood, S., Hughes, G. B., and Thomas, V. G. (2010). A guide to conducting_culturally responsive evaluations. In J. Frechtling (Ed.) The 2010 user-friendly handbook for project evaluation (pp. 75-96). Arlington, VA: National Science Foundation.

Greenblatt, J. (2017, June 30). Anti-Semitism is creeping into progressivism. Time. Retrieved from http://time.com/4839592/anti-semitism-lgbtq-chicago-pridemarch-zionism-anti-defamation-league/.

Greene, J., Barden, S., Richardson, E., \& Hall, K. (2014). The influence of film and experiential pedagogy on multicultural counseling self-efficacy and multicultural counseling competence. Journal of the Scholarship of Teaching and Learning, 14(5), 62-78.

Haupt, B., Kapucu, N., \& Hu, Q. (2017). Core competencies in Master of Public Administration programs: Perspectives from local government managers. Journal of Public Affairs Education, 23(1), 611-624.

Hood, S., Hopson, R. K., \& Kirkhart, K. E. (2015). Culturally responsive evaluation: Theory, practice, and future implications. In. K. E. Newcomer, H. P. Hatry, and J. S. Wholey (Eds.), Handbook of practical program evaluation, Fourth Edition (pp. 281-317). Hoboken, NJ: John Wiley and Sons.

hooks, b. (2009). Teaching critical thinking: Practical wisdom. Routledge.

Interfaith Diversity Experiences and Attitudes Longitudinal Study [IDEALS] (2018). The Interfaith Diversity Experiences and Attitudes Longitudinal Survey. Retrieved from https://www.ifyc.org/assessment/ideals.

Jacobs, J. (2018, May 18). How to tell when criticism of Israel is actually antiSemitism. The Washington Post. Retrieved from https://www.washingtonpost.com/outlook/how-to-tell-when-criticism-of-israelis-actually-anti-semitism/2018/05/17/cb58bf10-59eb-11e8-b656a5f8c2a9295d_story.html?utm term=.01b3db8b2544 (Accessed April 15, 2019).

Kirschen, Y. (2010). Mimetics and the Viral Spread of Antisemitism through "Coded Images" in Political Cartoons. In C. Small (Ed.) The Yale Papers: Antisemitism in Comparative Perspective. New York, NY: Institute for the Study of Global Antisemitism and Policy. 
Koren, A., Saxe, L., \& Fleish, E. (2016). Jewish life on campus: From backwater to battleground. In A. Dashefsky, I. Sheskin (eds.), American Jewish Year Book 2015. American Jewish Year Book 115, 45-88.

Kosmin, B. A. \& Keysar, A. (2015). National Demographic Survey of American Jewish College Students 2014: Anti-Semitism Report. Louis D. Brandeis Center for Human Rights Under Law and Trinity College. Retrieved from:

https://digitalrepository.trincoll.edu/cgi/viewcontent.cgi?referer=https://www.go ogle.com $/ \&$ httpsredir $=1 \&$ article $=1133 \&$ context $=$ facpub.

Lebovic, Matt. (2018, August 23). What's in a hyphen? Why writing anti-Semitism with a dash distorts its meaning. The Times of Israel. Retrieved from https://www.timesofisrael.com/whats-in-a-hyphen-why-writing-antisemitism-with-a-dash-distorts-its-meaning/.

Lipka, M. (October 2, 2013). How many Jews are there in the United States? Retrieved from https://www.pewresearch.org/fact-tank/2013/10/02/how-many-jews-arethere-in-the- $\% 09$ united-states/.

Lopez-Littleton, V., \& Blessett, B. (2015). Journal of Public Affairs Education A Framework for Integrating Cultural Competency into the Curriculum of Public Administration Programs. Journal of Public Affairs Education, 21(4), 557-574. https://doi.org/10.1080/15236803.2015.12002220.

Loucaides, D. (2019, March 8). The anti-Semitism crisis tearing the UK Labour Party apart, explained. Vox. Retrieved from https://www.vox.com/world/2019/3/8/18249953/uk-labour-party-anti-semitismjeremy-corbyn-juliana-berger.

Love, J. M., Gaynor, T. S., \& Blessett, B. (2016). Facilitating difficult dialogues in the classroom: A pedagogical imperative. Administrative Theory \& Praxis, 38, 227233.

Marcus, K. (2015). The ideology of the New Antisemitism. In Rosenfeld (Ed.), Deciphering the New Antisemitism. Bloomington, IN: Indiana University Press.

Masci, D. (2016). How income varies among U.S. religious groups. Factlink: News in the numbers. Pew Research Center. Retrieved from https://www.pewresearch.org/fact-tank/2016/10/11/how-income-varies-amongu-s-religious-groups/.

Mayhew, M. J., Bowman, N. A., Rockenbach, A. N., Selznick, B., \& Riggers-Piehl, T. (2018). Appreciative attitudes toward Jews among non-Jewish U.S. college students. Journal of College Student Development, 51(1), 71-89. https://muse.jhu.edu/article/684433.

McChesney, R. D. (1995). Charity and philanthropy in Islam: Institutionalizing the call to do good (No. 14). Indiana University Center on Philanthropy.

Melendez, P. (2018, October 29). Muslim communities raise thousands for families of Pittsburgh shooting victims. Daily Beast. Retrieved from https://www.thedailybeast.com/muslims-communities-raise-thousands-forfamilies-of-pittsburgh-shooting-victims/.

Meyer, J. W., \& Rowan, B. (1977). Institutionalized Organizations: Formal Structure as Myth and Ceremony. American Journal of Sociology, 83(2), 340-363. https://doi.org/10.1086/226550.

Nelson, C. \& Other Members of the Alliance for Academic Freedom. (2018, June 12). What's Wrong with the Anti-Semitism Awareness Act. Inside Higher Ed. Retrieved from https://www.insidehighered.com/views/2018/06/12/criticism-antisemitism-awareness-act-opinion. 
Newhouse, A. (2018, October 29). American Yartzheit. Tablet. Retrieved from https://www.tabletmag.com/jewish-news-and-politics/273679/americanyahrzeit.

Pagano, J-P. (2018, March 8). The Women's March has a Farrakhan Problem. The Atlantic. Retrieved from https://www.theatlantic.com/politics/archive/2018/03/womens-march/555122/.

Pew Research Center. (2012). The Global Religious Landscape. Retrieved from http://www.pewforum.org/2012/12/18/global-religious-landscape-exec/.

Pew Research Center. (2013). A Portrait of Jewish Americans. Retrieved from: http://www.pewforum.org/2013/10/01/jewish-american-beliefs-attitudes-culturesurvey.

Philogos. (2012, November 18). Should anti-Semitism be hyphenated? Forward. Retrieved from https://forward.com/culture/166092/should-anti-semitism-behyphenated/.

Pildis, C. (2018a, April 22). It's not (only) about Farrakhan. Tablet. Retrieved from https://www.tabletmag.com/jewish-news-and-politics/260428/tamika-mallorystop-bringing-hate-into-the-womens-march.

Pildis, C. (2018b, October 27). The right has blood on its hands after Pittsburgh - and so does the left. Tablet. Retrieved from https://forward.com/opinion/412838/theright-has-blood-on-its-hands-after-pittsburgh-carnage-and-so-does-the/.

Pildis, C. (2019, January 4). Why I still want the Women's March to Succeed. Tablet. Retrieved from https://www.tabletmag.com/scroll/278050/why-i-still-want-thewomens-march-to-succeed.

Price, JF \& Silverman, EH. (2019, June 2017). Combating Anti-Semitism in the Classroom Should Not Fall to Jews. The Forward. Retrieved from https://forward.com/opinion/426018/combatting-anti-semitism-in-theclassroom-should-not-fall-to-jews/.

Rockenbach, A. N., Selznick, B. S., \& Mayhew, M.J. (2018, June 27). What New Data Say About Improving Attitudes Toward Jewish Students. Inside Higher Ed. Retrieved from https://www.insidehighered.com/views/2018/06/27/what-newdata-say-about-improving-attitudes-toward-jewish-students-opinion.

Rosenfeld, A. H. (Ed.). (2015). Deciphering the new antisemitism. Bloomington, IN: Indiana University Press.

Rubin, D. I., (2017). Whiter shade of pale: Making the case for Jewish presence in the multicultural classroom. International Journal of Multicultural Education, 19(2), 131-145.

Ryan, S. E. (2012). Assessing diversity in public affairs curricula: A multimethodological model for student-led programmatic self-study. Journal of Public Affairs Education, 18(4), 757-774.

Sabbagh, D. (2019, February 22). Labour MP Ian Austin quits the party over 'culture of anti-Semitism.' The Guardian. Retrieved from https://www.theguardian.com/politics/2019/feb/22/labour-mp-ian-austin-quitsthe-party (Accessed April 15, 2019).

Saxe, L., Sasson, T., Wright, G., \& Hecht, S. (2015). Antisemitism on the college campus: Perceptions and realities. Waltham, MA: Cohen Center for Modern Jewish Studies, Brandeis University.

Schmidt, S. (2019, January 15). Will Jewish women attend the Women's March amid allegations of anti-Semitism? The Washington Post. Retrieved from https://wapo.st/2FwPPQK?tid=ss tw\&utm term=.766b512b2113 (Accessed April 15, 2019). 
Schneider, A., \& Ingram, H. (1993). Social construction of target populations: Implications for politics and policy. American political science review, 87(2), 334-347.

Schraub, D. (2019, Feb. 13). When the right and left fight over anti-Semitism, Jews are caught in the middle. Jewish Telegraphic Agency. Retrieved from https://www.jta.org/2019/02/13/opinion/when-the-right-and-left-fight-over-antisemitism-jews-are-caught-in-the-middle (Accessed April 16, 2019).

Schuffman, S. (2019, January 17). Manny's is a perfect business for The Mission. San Francisco Examiner. Retrieved from http://www.sfexaminer.com/mannysperfect-business-mission/.

Simon, R. J. and Schaler, J. A. (2007). Anti-Semitism the World Over in the Twentyfirst Century. Current Psychology, 26(3-4), 152-182.

Starke, A. M., Heckler, N., \& Mackey, J. (2018). Administrative racism: Public administration education and race. Journal of Public Affairs Education, 24(4), 469-489.

Stockman, F. (2018, December 23). Women's March roiled by accusations of antiSemitism. The New York Times. Retrieved from https://www.nytimes.com/2018/12/23/us/womens-march-anti-semitism.html (Accessed April 15, 2019).

Trump, Donald J. [realDonaldTrump]. (2018, October 5). The very rude elevator screamers are paid professionals only looking to make Senators look bad. Don't fall for it! Also, look at all of the professionally made identical signs. Paid for by Soros and others. These are not signs made in the basement from love! \#Troublemakers. Retrieved from https://twitter.com/realDonaldTrump

United States Holocaust Memorial Museum [USHMM]. (n.d.). "Antisemitism: The longest hatred.” Retrieved from https://www.ushmm.org/confrontantisemitism/antisemitism-the-longest-hatred (Accessed January 29, 2019).

U.S. House Committee on The Judiciary. (2017). Hearing examining anti-Semitism on college campuses. Retrieved from https://judiciary.house.gov/hearing/examining-anti-semitism-college-campuses.

Vigdor, N. and Beals, S.R. (2018, October 30). Republican campaign mailer fuels antiSemitism complaints in state senate race. Hartford Courant. Retrieved from https://www.courant.com/politics/hc-pol-anti-semitic-mailer-20181030story.html.

Walker, S. (2018, March 15). Hungarian leader says Europe is now 'under invasion' by migrants. The Guardian. Retrieved from https://www.theguardian.com/world/2018/mar/15/hungarian-leader-says-europeis-now-under-invasion-by-migrants.

Ward, E. K. (2017). Skin in the game: How antisemitism animates White Nationalism. The Public Eye: Political Research Associates, Challenging the Right, Advancing Social Justice, 1-8.

Wistrich, R. S. (1992). Anti-Semitism: The Longest Hatred. London: Pantheon.

Wright, G., Shain, M., Hecht, S., \& Saxe, L. (2017). The limits of hostility: Students report on anti-Semitism and anti-Israel sentiment at four US universities. Brandeis University Steinhardt Social Research Institute. Retrieved from: https://www.brandeis.edu/ssri/pdfs/campusstudies/LimitsofHostility.pdf. 
Table 1. Course-specific suggestions for addressing antisemitism

\begin{tabular}{|c|c|c|c|}
\hline $\begin{array}{l}\text { Course } \\
\text { Topic }\end{array}$ & $\begin{array}{l}\text { Lesson } \\
\text { Objective(s) }\end{array}$ & $\begin{array}{l}\text { Assignments and/or } \\
\text { Activities }\end{array}$ & Cultural Competencies \\
\hline $\begin{array}{l}\text { Public } \\
\text { management }\end{array}$ & $\begin{array}{l}\text { Antisemitism or } \\
\text { Jews in the context } \\
\text { of social } \\
\text { construction of } \\
\text { target populations }\end{array}$ & $\begin{array}{l}\text { Current events, critical } \\
\text { theory, case studies }\end{array}$ & $\begin{array}{l}\text { Incorporates strategies for interacting } \\
\text { with persons from diverse backgrounds } \\
\text { Recognizes the ways diversity influences } \\
\text { policies, programs, and services }\end{array}$ \\
\hline $\begin{array}{l}\text { Nonprofit } \\
\text { management }\end{array}$ & $\begin{array}{l}\text { Fundraising } \\
\text { Community } \\
\text { mobilization in } \\
\text { response to } \\
\text { antisemitism }\end{array}$ & $\begin{array}{l}\text { Current events, critical } \\
\text { theory, case studies, readings } \\
\text { on historical and religious } \\
\text { giving motivations; } \\
\text { philanthropy roadmap }\end{array}$ & $\begin{array}{l}\text { Incorporates strategies for interacting } \\
\text { with persons from diverse backgrounds } \\
\text { Recognizes the ways diversity influences } \\
\text { policies, programs, and services }\end{array}$ \\
\hline $\begin{array}{l}\text { Public } \\
\text { policy }\end{array}$ & $\begin{array}{l}\text { Differential policy } \\
\text { impacts in diverse } \\
\text { communities } \\
\text { Policy responses to } \\
\text { antisemitism }\end{array}$ & $\begin{array}{l}\text { Case studies with differential } \\
\text { impact on Jewish populations } \\
\text { and discuss implications for } \\
\text { Jews in particular; analysis of } \\
\text { policy responses to } \\
\text { antisemitic events and hate } \\
\text { crimes }\end{array}$ & $\begin{array}{l}\text { - Recognizes the ways diversity influences } \\
\text { policies, programs, and services } \\
\text { Supports diverse perspectives in } \\
\text { developing, implementing, and } \\
\text { evaluating policies, programs, and } \\
\text { services that affect the health of a } \\
\text { community } \\
\text { Conveys data and information to } \\
\text { professionals and the public using a } \\
\text { variety of approaches }\end{array}$ \\
\hline Evaluation & $\begin{array}{l}\text { Culturally } \\
\text { responsive } \\
\text { evaluation }\end{array}$ & $\begin{array}{l}\text { Use an equity toolkit as a } \\
\text { model to evaluate differential } \\
\text { impacts of programs on Jews }\end{array}$ & $\begin{array}{l}\text { - Recognizes the ways diversity influences } \\
\text { policies, programs, and services } \\
\text { Supports diverse perspectives in } \\
\text { developing, implementing, and } \\
\text { evaluating policies, programs, and } \\
\text { services that affect the health of a } \\
\text { community } \\
\text { Conveys data and information to } \\
\text { professionals and the public using a } \\
\text { variety of approaches } \\
\text { Develops new and/or evaluates existing } \\
\text { social equity indicators, tools, and } \\
\text { measurements }\end{array}$ \\
\hline $\begin{array}{l}\text { Human } \\
\text { resources }\end{array}$ & $\begin{array}{l}\text { Antisemitism in a } \\
\text { work environment; } \\
\text { diversity initiatives }\end{array}$ & $\begin{array}{l}\text { Draft sample HR policies } \\
\text { with inclusive language }\end{array}$ & $\begin{array}{l}\text { Incorporates strategies for interacting } \\
\text { with persons from diverse backgrounds } \\
\text { Recognizes the ways diversity influences } \\
\text { policies, programs, and services }\end{array}$ \\
\hline $\begin{array}{l}\text { Research } \\
\text { methods }\end{array}$ & $\begin{array}{l}\text { Antisemitism in the } \\
\text { context of data, } \\
\text { interviewing }\end{array}$ & $\begin{array}{l}\text { Interrogate demographic data } \\
\text { on race and religion given the } \\
\text { complexity of Jewish } \\
\text { identity; use data to examine } \\
\text { trends in antisemitism; } \\
\text { discuss how correlations } \\
\text { among variables such as } \\
\text { religion, education, and } \\
\text { wealth can facilitate } \\
\text { stereotyping and prejudice }\end{array}$ & $\begin{array}{l}\text { Incorporates strategies for interacting } \\
\text { with persons from diverse backgrounds } \\
\text { Conveys data and information to } \\
\text { professionals and the public using a } \\
\text { variety of approaches } \\
\text { - Develops new and/or evaluates existing } \\
\text { social equity indicators, tools, and } \\
\text { measurements }\end{array}$ \\
\hline
\end{tabular}




\section{Appendix A: Online Only \\ Select Recommended Resources Related to Antisemitism}

\section{Resources for Background and Class Assignments/Activities}

Green, E. (2019, May 25). Measles can be contained. Anti-Semitism cannot. The Atlantic. Retrieved from https://www.theatlantic.com/politics/archive/2019/05/orthodox-jews-face-antisemitism-after-measles-outbreak/590311/.

Jacobs, J. (2018, May 18). How to tell when criticism of Israel is actually antiSemitism. The Washington Post. Retrieved from https://www.washingtonpost.com/outlook/how-to-tell-when-criticism-of-israelis-actually-anti-semitism/2018/05/17/cb58bf10-59eb-11e8-b656a5f8c2a9295d_story.html. (Accessed April 15, 2019).

Jews for Racial \& Economic Justice (2017). Understanding Anti-Semitism: An Offering to our Movement. Retrieved from: https://jfrej.org/wpcontent/uploads/2017/11/JFREJ-Understanding-Antisemitism-November-2017$\underline{1 . p d f}$

Schraub, D. (2019, Feb. 13). When the right and left fight over anti-Semitism, Jews are caught in the middle. Jewish Telegraphic Agency. Retrieved from https://www.jta.org/2019/02/13/opinion/when-the-right-and-left-fight-over-antisemitism-jews-are-caught-in-the-middle (Accessed April 16, 2019).

UNESCO. Addressing anti-semitism through education: Guidelines for policymakers. Retrieved from https://unesdoc.unesco.org/ark:/48223/pf0000263702.

Ward, E. K. (2017). Skin in the game: How antisemitism animates White Nationalism. The Public Eye: Political Research Associates, Challenging the Right, Advancing Social Justice, 1-8.

\section{Institutions/Organizations}

- Cohen Center for Modern Jewish Studies: https://www.brandeis.edu/cmjs/

- Steinhardt Social Research Institute: https://www.brandeis.edu/ssri/

- Hadassah-Brandeis Institute: https://www.brandeis.edu/hbi/index.html

- Institute for the Study of Contemporary anti-Semitism: https://isca.indiana.edu/index.html

- Mandel Center for Studies in Jewish Education: https://www.brandeis.edu/mandel/

\section{Additional Resources}

- Anti-Defamation League: https://www.adl.org

- Calendar of major Jewish holidays: https://www.myjewishlearning.com/article/calendar-of-major-jewish-holidays/

- Hillel on campus: https://www.hillel.org

- Federal Bureau of Investigation Hate Crime Statistics: https://ucr.fbi.gov/hatecrime $/ 2017$

- Jews for Racial and Economic Justice: https://www.jfrej.org 


\section{Appendix B: Online Only \\ Sample Language and Spreadsheet for Religious Accommodations}

Email from Dean:

Hi everyone,

I hope this email finds you all enjoying a bit less hectic schedule now that summer is here.

As part of our goal of avoiding scheduling that causes individuals to have to choose between religious observances and work or school obligations, XX has put together the following list of holidays that we are aware of over the next year. Please consider these dates when making plans for events/ meetings etc.

As you may know, it is challenging to identify an "exhaustive" list so if you are aware of other observances we should add, please don't hesitate to contact [contact person]. I also welcome any feedback, questions or concerns with the process.

We hope this helps advance our efforts to have a "welcoming campus, welcoming classroom, welcoming workplace".

Thanks to [contact person] and several others who provided sage advice on where to locate the information compiled here. 


\begin{tabular}{|c|c|c|c|}
\hline Fall 2019 & & & \\
\hline Holiday or Observance & Religious Group & Dates & Additional Notes \\
\hline Eid-al-Adha & Muslims Muslim & Aug. 11, 2019 & \\
\hline Ra's as-Sanah (New Year) & Muslims & Sept. 1, 2019 & \\
\hline Labor Day & & Sept. 2, 2019 & Class not in session \\
\hline Ashura & Muslims & Sept. 9, 2019 & \\
\hline Navaratri/Dassehra & Hindu & Sept. 29-Oct. 7, 2019 & \\
\hline Rosh Hashanah (New Year) & Jewish & Sept. 29-Oct. 1, 2019 & $\begin{array}{l}\text { begins sundown } 9 / 29 \text {, ends sundown } 10 / 1 \text {; } \\
\text { observant students may miss class }\end{array}$ \\
\hline Yom Kippur (Day of Atonement) & Jewish & Oct. 8-9, 2019 & $\begin{array}{l}\text { sundown to sundown; observant students } \\
\text { may miss class and/or be fasting }\end{array}$ \\
\hline Sukkot (Feast of Tabernacles) & Jewish & Oct. 13-20, 2019 & $\begin{array}{l}\text { Oct. 13-15 Primary Obligation Days } \\
\text { (sundown to sundown); observant } \\
\text { students may miss class on the first two } \\
\text { and/or last two days }\end{array}$ \\
\hline Simchat Torah & Jewish & Oct. 21,2019 & observant students may miss class \\
\hline Diwali & Hindu & Oct. 27,2019 & \\
\hline Mawlid-al-Nabi (birthday of Mohammad) & Muslims & Nov. 10, 2019 & \\
\hline Veteran's Day & & Nov. 11, 2019 & \\
\hline Thanksgiving Day break & & Nov. 28-29, 2019 & Class not in session \\
\hline Hanukkah (Chanukah) & Jewish & Dec. $22-30,2019$ & \\
\hline Christmas Day & Christian & Dec. 25,2019 & Class not in session \\
\hline \multicolumn{4}{|l|}{ Spring 2020} \\
\hline Holiday or Observance & Religious Group & Dates & Additional Notes \\
\hline New Year's Day & & Jan. 1,2020 & Class not in session \\
\hline Orthodox Christmas & Christian Orthodox & Jan. 7,2020 & \\
\hline Martin Luther King Day & & Jan. 20, 2020 & Class not in session \\
\hline President's Day & & Feb. 17,2020 & \\
\hline Maha Shivaratri & Hindu & Feb. 21,2020 & \\
\hline Beginning of Lent/Ash Wednesday & $\begin{array}{l}\text { Christian Orthodox/ } \\
\text { Christian }\end{array}$ & Feb. 26, 2020 & \\
\hline Holi & Hindu & Mar. $9-10,2020$ & \\
\hline Purim & Jewish & Mar. 10, 2020 & starts sundown Mar 9 \\
\hline Lailat al Miraj & Muslims & Mar. 23,2020 & \\
\hline Ramanavami & Hindu & Apr. 2,2020 & \\
\hline Laylat al-Bara' & Muslims & Apr. 9,2020 & \\
\hline Passover (Pesach) & Jewish & Apr. 8-15, 2020 & $\begin{array}{l}\text { starts sundown April 8, observant } \\
\text { students may miss class April } 8 \text { (evening), } \\
\text { April } 9 \text { or between sundown-sundown } \\
\text { April 14-16, certain foods restricted <-- } \\
\text { keep this in mind when planning events } \\
\text { with food }\end{array}$ \\
\hline Good Friday & Christian & Apr. 10,2020 & \\
\hline Easter & Christian & Apr. 12,2020 & \\
\hline Orthodox Good Friday & Christian Orthodox & Apr. 17,2020 & \\
\hline Orthodox Easter & Christian Orthodox & Apr. 19,2020 & \\
\hline Beginning of Ramadan & Muslims & Apr. 24,2020 & $\begin{array}{l}\text { Ramadan: Apr. 24-May } 24,2020 \text {, students } \\
\text { fast from sunrise to sundown every day }\end{array}$ \\
\hline \multicolumn{4}{|l|}{ Summer 2020} \\
\hline Holiday or Observance & Religious Group & Dates & Additional Notes \\
\hline Lailat UI Qadr & Muslims & May 20, 2020 & \\
\hline Eid al-Fitr (End of Ramadan) & Muslims & May 24, 2020 & Ramadan: Apr. 24-May 24, 2020 \\
\hline Memorial Day & & May 25,2020 & Class not in session \\
\hline Shavuot & Jewish & May 28-30, 2020 & $\begin{array}{l}\text { sundown-sundown, observant students } \\
\text { may miss class }\end{array}$ \\
\hline Independence Day & & July 4, 2020 & Class not in session \\
\hline Eid-al-Adha & Muslims & July 30,2020 & \\
\hline Janmashtami & Hindu & Aug. 10,2020 & \\
\hline
\end{tabular}

